\title{
The effect of Eurasian Economic Union on trade of Kazakhstan: impact evaluation using the Synthetic Control Method
}

\author{
Bolat M. Mukhamediyev ${ }^{1}$, Zhansaya S. Temerbulatova ${ }^{2}$, Guliya K.Ilyashova ${ }^{3}$
}

Received: March 09, 2020 Revised: March 23, $2020 \quad$ Accepted: April 07, 2020

\section{Түйін}

Интеграциялық процестер аясында елдердің сауда саясаты жеке елдің де, тұтас интеграциялық бірлестіктің де бәсекеге қабілеттілігіне айтарлықтай әсер етеді. Мақалада Еуразиялық экономикалық одақтың Қазақстан мен интеграциялық блокқа мүше басқа елдер арасындағы екіжақты саудаға әсері бағаланады. Зерттеудің мақсаты ЕАЭО-ға кіргеннен кейінгі Қазақстан үшін сауданың пайдасын талдау. Синтетикалық бақылау әдісі қолданылды. Бұл әдіс аздаған мысалдарды қолдана отырып, гипотетикалық жағдайда әсер ету болмаған кезде олардың сандық көрсеткіштерін модельдеу арқылы бағалауға бағытталған. Модельдеу үшін 1995-2018 жылдарға арналған Қазақстан мен 40 донор елден деректер жиналды. Осы мәліметтер негізінде Қазақстанның сипаттамаларына өте ұқсас синтетикалық контрафакциялық бірлік құрастырылды. Зерттеу нәтижесінде егер Қазақстан ЕАЭО-ға кірмесе, оның ЕАЭО елдерімен екіжақты сауда ағындары 2018 жылы 18,5\%-ға аз болатыны анықталды. Дәл осы әдістеме бойынша Қазақстанның ЕАЭО-ның әр елімен екіжақты саудасы жеке-жеке бағаланды.

Түйінді сөздер: Еуразиялық экономикалық одақ, екіжақты сауда, интеграция, синтетикалық бақылау әдісі, донорлық пул, контрафакциялық бірлік, әсер ету.

Within the framework of integration processes, the trade policies of countries significantly affect the competitiveness of both a single country and the entire integration association. The article provides the evaluation of impact of the Eurasian Economic Union on bilateral trade between Kazakhstan and other member countries of the integration bloc. The aim of the study is to analyze the trade benefits for Kazakhstan after joining the EAEU. The synthetic control method was used. The method is aimed at assessing the effects of the impact using a small number of cases as an example of modeling their quantitative indicators in a hypothetical situation where there was no impact. For modeling data from Kazakhstan and 40 donor pool countries for 1995-2018 were collected. Based on the data, a synthetic counterfactual unit, which best resembles the characteristics of the Kazakhstan, was constructed. As a result of the study, it was determined that bilateral trade flows of Kazakhstan with the EAEU countries in 2018 would have been 18.5 less if Kazakhstan had not joined the EAEU. Also, according to a similar method, an assessment of bilateral trade of Kazakhstan with each EAEU country was carried out separately.

Keywords: Eurasian Economic Union, bilateral trade, integration, synthetic control method, donor pool, counterfactual unit, treatment.

\section{Аннотация}

В рамках интеграционных процессов торговая политика стран существенно влияет на конкурентоспособность как отдельной страны, так и всей интеграционной ассоциации. В статье проведена оценка влияния Евразийского экономического союза на двустороннюю торговлю между Казахстаном и другими странами - членами интеграционного блока. Целью исследования является анализ торговых выгод для Казахстана после вступления в ЕАЭС. Был использован метод синтетического контроля. Метод нацелен на оценку последствий воздействия с использованием небольшого числа случаев в качестве примера моделирования их количественных показателей в гипотетической ситуации, когда воздействия не было. Для моделирования были собраны данные Казахстана и 40 стран-доноров за 1995-2018 гг. На основании этих данных была построена синтетическая контрфактическая единица, которая больше всего схожа с характеристиками Казахстана. В результате исследования было установлено, что двусторонние торговые потоки Казахстана со странами ЕАЭС в 2018 г. были бы на 18,5\% меньше, если бы Казахстан не присоединился бы к ЕАЭС. Также по аналогичной методике, была проведена оценка двусторонней торговли Казахстана с каждой страной ЕАЭС по отдельности.

Ключевые слова: Евразийский экономический союз, двусторонняя торговля, интеграция, синтетический метод контроля, пул доноров, контрфактическая единица, воздействие.

1 Doctor of Economic Sciences, Professor, Al-Farabi Kazakh National University, Kazakhstan, Almaty, e-mail: bmukhamediyev@mail. ru, ORCID iD: https://orcid.org/0000-0002-1490-302X

2 Doctoral student, Al-Farabi Kazakh National University, Kazakhstan, Almaty, e-mail: t.zhansaya.s@mail.ru, ORCID iD:https://orcid. org/0000-0002-3205-0948

3 Senior Lecturer, Al-Farabi Kazakh National University, Kazakhstan, Almaty, e-mail: guliya_ilyashova@mail.ru 


\section{Introduction}

In the era of globalization, countries are actively joining integration associations, since integration is a powerful tool for accelerating the development of regional economies and increasing competitiveness in the world market. Integrating countries expect to improve the functioning of national economies, take advantage of the economies of scale, reduce transaction costs, create a favorable foreign policy environment, a stable environment, and also solve the problems of trade policy. In order for the integration association to work successfully, a combination of a number of factors is necessary, such as approximately the same level of socio-economic development, the growth rate of the GDP of the participating countries; the geographical proximity and the cultural and historical community of the countries are also of great importance.

Almost every country in the world takes part in one or another integration economic grouping. According to the degree of strengthening the interdependence of countries, the following types of integration associations are distinguished: a free trade area, a customs union, a common market, an economic union, and full (economic and political) integration.

The Eurasian Economic Union (EAEU), founded in 2015, has passed all the above stages of development. In 1994, President of Kazakhstan N. Nazarbayev introduced the concept of integration in the Eurasian space, and also outlined the key principles and practical steps for its implementation. In the same year, the presidents of the countries of the Commonwealth of Independent States (CIS) signed an agreement on a free trade zone, in 2000 the Treaty establishing the Eurasian Economic Community was signed, and in 2010 the Customs Union, which included Kazakhstan, Russia and Belarus, began to function, and these countries moved to the next stage of integration construction - the Common Economic Space in 2012.

On May 29, 2014, the leaders of Russia, Belarus and Kazakhstan signed an agreement on the Eurasian Economic Union, which entered into force on January 1,2015 . The creation of the union takes member countries to a higher level of integration, which ensures the freedom of movement of goods, as well as services, capital and labor, and conducts a coordinated policy in economic sectors [1].

The main objective of the study is to analyze the trade benefits for Kazakhstan after joining the EAEU. The synthetic control method (SCM) used to do this. The method is aimed at assessing the effects of the impact (in this case, joining of Kazakhstan the integration association) using a small number of cases as an example of modeling their quantitative indicators in a hypothetical situation where there was no impact.

The article consists of five sections. Section 2 contains literature review, which examines studies using the synthetic control method. Section 3 describes the synthetic control method and data sources. Section 4 presents empirical results, and section 5 highlights the findings.

\section{Literature Review}

Researchers often try to assess the impact of a particular event or political intervention on a specific subject (firm, region, country). To do this, we can use the statistical method that evaluates the effect of intervention in comparative case studies. The synthetic control method (SCM) was developed by Abadie and Gardeazabal in 2003 and expanded by Abadie et al. in 2010 [2, 3].

This method is widely used in various fields of economic science. For example, Abadie and Gardeazabal evaluated what economic growth in a Basque Country would have been in the absence of terrorism. The result of the study showed that after the outbreak of terrorism, per capita GDP in Basque Country fell by about $10 \%$ compared with a synthetic control region without terrorism [2].

In a study by Abadie et al. examined the effect of Proposition 99, a large-scale tobacco control program that California implemented in 1988. The assessment showed that after the introduction of this program, annual per capita cigarette sales in California fell by 26 packs compared to synthetic group of states [3].

Demko et al. used the synthetic control method to study the impact of bilateral organic equivalence agreement between the European Union and the United States. After analyzing 23 US organic product exports, it was concluded that, after the agreement, organic product exports to the European Union increased by $9.1 \%$ every quarter [4].

Saia estimated how the UK trade flow with the EU countries would have changed if they had adopted the single euro currency. For this, he used data from the UK and 9 countries that are members of the European Union and adopted the euro for 1980-2012. As a result of the study, it was concluded that the total trade flows between the UK and members of the eurozone would be $16 \%$ higher if the UK adopted the euro $[5,6]$.

Nwe et al. assessed the impact of a constitutional referendum on economic growth in Myanmar. For this, the authors calculated counterfactual GDP per capita for the period from 2002 to 2013, using data from developing countries of East and South Asia, the Pacific Ocean and sub-Saharan Africa as a control group. As a result, it was determined that the process of political change in Myanmar had a positive and significant impact on per capita GDP, but not on foreign direct investment or per capita trade [7].

In our case, the most interesting are studies aimed at assessing the impact of integration on country's economy. For example, in study by Campos et al. counterfacts were built for countries that joined the European Union from 1973 to 2004. Despite significant differences between countries, the assessment showed 
that without European integration, per capita income would be on average about $10 \%$ lower [8].

The synthetic control method is also used to assess the impact of a potential agreement. For example, Hosny assessed the impact of Algeria's late accession (in 2005) to the Agreement on the Large Arab Free Trade Area (GAFTA), which was signed in 1998. The evaluation results showed that Algeria's trade with nine GAFTA member countries would have been much better if Algeria had signed the agreement in 1998 [9].

Some studies are aimed at assessing the counterfact situation in the country using synthetic controls in the absence of intervention. Then the counterfactual shows what the result would have been in the country if the intervention had not occurred. For example, in the paper of Aytug et al. the result of the assessment showed that if a customs union between Turkey and the European Union had not been created in 1995, Turkey's exports to the EU and per capita GDP in 2013 would have been 38 and 13 percent less, respectively [10].

Also, the synthetic control method allows us to evaluate not only the quantitative change in trade under the influence of integration processes, but also the qualitative indicators of the trade structure. Gabrielczak and Serwach have empirically proven that after joining the EU, the complexity of exported goods in Slovakia increased due to an increase in foreign direct investment flows [11]. Stojcic et al. concluded that accession to the EU increased the quality of exports and the share of high-tech industries in its structure in all EU countries [12].

\section{Methodology and Data}

Differently from previous literature, in this empirical exercise, we use non-parametric estimates to control for possible biases due to the non-linearitywith-self-selection problem linked to the use of loglinear gravity equations. Specifically, since we are interested in evaluating the specific impact of EAEU partnership on the bilateral trade of each specific partner country, we apply a SCM.

The synthetic control method is a statistical method used to evaluate the effect of an intervention in comparative case studies. It involves the construction of a weighted combination of groups used as controls, to which the treatment group is compared.

Since in this case, we are aware that the source of self-selection is proness to trade, as in $[13,14]$, we take here advantage of the theoretical underpinnings of the gravity equation to remove self-selection. Specifically, to build up a sound counterfactual we model the synthetic cohort by using the standard gravity variables, that is the size of trading economies as measured by their GDP values, and trade frictions as measured by their bilateral geographical distance. The model is also supplemented by additional factors that are considered important for explaining the trade. In our case, the gravitational model of trade has the following form:

$$
\ln B T_{i j t}=\operatorname{lnGDP_{ijt}}+\operatorname{lnDist}_{i j}+\operatorname{lnPOP_{i}}+\text { Lang }+\varepsilon_{i j t}
$$

Two samples are considered: in the first example bilateral trade between Kazakhstan and the four other countries participating in the association (Russia, Belarus, Armenia, Kyrgyzstan) is estimated, in the second sample, bilateral trade between pairs of countries is evaluated: KazakhstanRussia, Kazakhstan-Belarus, Kazakhstan-Armenia, Kazakhstan-Kyrgyzstan.

Table 1 - Description of variables

\begin{tabular}{|c|c|c|}
\hline Variables & $1^{\text {st }}$ sample & $2^{\text {nd }}$ sample \\
\hline $\ln B T_{i j t}$ & $\begin{array}{c}\text { logarithm of bilateral trade between and countries, where } \\
\text { - EAEU member-countries except Kazakhstan (Russia, } \\
\text { Belarus, Armenia, Kyrgyzstan) }\end{array}$ & $\begin{array}{c}\text { bilateral trade between and countries, } \\
\text { where - Russia, Belarus, Armenia, Kyrgyz- } \\
\text { stan separately }\end{array}$ \\
\hline $\ln G D P_{i j t}$ & $\begin{array}{l}\text { logarithm of aggregate GDP of country and average GDP } \\
\text { of countries, where - EAEU member-countries except } \\
\text { Kazakhstan (Russia, Belarus, Armenia, Kyrgyzstan) }\end{array}$ & $\begin{array}{l}\text { logarithm of aggregate GDP of and coun- } \\
\text { tries, where - Russia, Belarus, Armenia, } \\
\text { Kyrgyzstan separately }\end{array}$ \\
\hline $\operatorname{lnDist}_{i j}$ & $\begin{array}{c}\text { logarithm of average distance between and countries based } \\
\text { on the location of capital cities, where - EAEU member- } \\
\text { countries except Kazakhstan (Russia, Belarus, Armenia, } \\
\text { Kyrgyzstan) }\end{array}$ & $\begin{array}{c}\text { logarithm of distance between and coun- } \\
\text { tries based on the location of capital cities, } \\
\text { where - Russia, Belarus, Armenia, Kyrgyz- } \\
\text { stan separately }\end{array}$ \\
\hline $\ln P O P_{i}$ & logarithm of country’s population & logarithm of country's population \\
\hline Lang & $\begin{array}{l}\text { dummy variable that takes the value } 1 \text { if } 20 \% \text { of population } \\
\text { in and even in one of countries speak on one language, and } 0 \\
\text { otherwise, where - EAEU member-countries except } \\
\text { Kazakhstan (Russia, Belarus, Armenia, Kyrgyzstan) }\end{array}$ & $\begin{array}{l}\text { dummy variable that takes the value } 1 \text { if } \\
20 \% \text { of population in and countries speak } \\
\text { on one language. and } 0 \text { otherwise, where } \\
\text { - Russia, Belarus, Armenia, Kyrgyzstan } \\
\text { separately }\end{array}$ \\
\hline$\varepsilon_{i j t}$ & error term & error term \\
\hline
\end{tabular}


The next stage of the analysis is the use of the synthetic control method for the constructed gravitational model.

Let be the outcome (bilateral trade) that would be observed for country (Kazakhstan) at time in the absence of the intervention (membership in the EAEU) for units and time periods Let be the intervention period, where . Let be the outcome observed for country at time when the country is exposed to the intervention between periods and. Then, the treatment effect (the impact of the intervention) for country can be defined as . However, is observed and is not observed between and. Thus, which is the counterfactual, must be estimated to find the impact of the intervention.

Abadie et al. show how to identify the treatment effect, , using the following model for potential outcomes [3]:

$$
\begin{gathered}
Y_{i t}^{0}=\delta_{t}+Z_{i} \theta_{t}+\lambda_{t} \mu_{i}+\varepsilon_{i t}, \\
Y_{i t}^{1}=\delta_{t}+\tau_{i t}+Z_{i} \theta_{t}+\lambda_{t} \mu_{i}+\varepsilon_{i t},
\end{gathered}
$$

where $Z_{i}$ is a vector of relevant observed covariates (either time-varying or time-invariant) that are not affected by the intervention, $Q_{t}$ a vector of parameters, $\lambda_{t}$ an unknown common factor, $\mu_{i}$ a country-specific unobservable, $\varepsilon_{i t}$ a transitory shock with a zero mean, and $\tau_{i t}$ a dummy variable that takes the value 1 for the treated unit, and 0 otherwise.

Suppose that the first country (Kazakhstan), $i=$ 1 , receives the treatment (membership in the EAEU) and the remaining $J$ countries, $i=2, \ldots, J+1$, do not. The proposed data-driven approach is to approximate $Y_{i t}^{0}$ by a weighted average of $Y_{i t}^{1}$, taking into account the covariates $Z$ for the pre-intervention period, $t \leq T_{0}$, such that:

$$
\begin{gathered}
Y_{1 t}=\sum_{i=2}^{J+1} w_{i}^{*} Y_{i t}, \\
Z_{1}=\sum_{i=2}^{J+1} w_{i}^{*} Z_{i}
\end{gathered}
$$

where the weights, $w_{i}$, satisfy $\sum_{i=2}^{J+1} w_{i}=1$ and $w_{i} \geq 0$. These two assumptions for the weights make sure that there is no extrapolation of outcomes from the model. Finally, the treatment effect can be estimated using:

$$
\widehat{\tau_{l t}}=Y_{1 t}-\sum_{i=2}^{J+1} w_{i}^{*} Y_{i t} \text { for } t=T_{0}+1, \ldots, T
$$

The main idea here is that the synthetic control imitates the counterfactual of the treated country that would have been observed in the absence of the intervention using the weighted average of all control countries. For the optimal choice of $W^{*}$, consider $\left.X_{l}=\left(Z_{l}, Y_{1 l}, \ldots, Y_{l T O}\right)\right)$ to be the vector of pre-intervention characteristics for country $i=1$, and $X_{0}=\left(Z_{i}, Y_{j p} \ldots, Y_{i T O}\right.$ ) to be the matrix of the same characteristics for the control units $j \in[2, j+1]$. Then the vector $W^{*}$ is chosen to minimize the distance between $X_{1}$ and $X_{0} W$, following:

$$
\begin{gathered}
\min _{W}\left\|X_{1}-X_{0} W\right\|_{v}=\min _{W(V)} \sqrt{\left(X_{1}-X_{0} W\right)^{\prime} V\left(X_{1}-X_{0} W\right)}, \\
\text { s.t. } w_{i} \geq 0 \text { for } i=2, \ldots, J+1 \text { and } \sum_{i=2}^{J+1} w_{i}=1,
\end{gathered}
$$

where $V$ is a $k \times k$ symmetric and positive semi-definite matrix, which measures the relative importance of the pre-intervention characteristics included in $X$. Thus, $W$ is a function of the elements of $V$. The minimization problem above provides a solution for $W^{*}\left(V^{*}\right)$ that minimizes the pre-intervention Root Mean Square Prediction Error (RMSPE) of the outcome over the control period. Thus, the accuracy of the approximation depends on the minimization problem, which is satisfied with a lower RMSPE. In other words, the SCM estimates the unobserved counterfactual as a weighted average of the outcomes of the control countries, with weights chosen to approximate the pre-intervention characteristics of the affected country [15].

When choosing control countries, Gardeazabal proposed limiting the set of potential control countries - the donor pool, creating a selection criterion [16]. In our case, 40 donor pool countries were selected that meet the following criteria:

1. Countries must be located on the Eurasian continent

2. Countries should not be members of the CIS, as there is also a free trade agreement between the CIS countries.

3. Availability of data on exports / imports, GDP and population since 1995 .

The analysis is based on a panel dataset spanning 41 countries over the period 1995-2018 at an annual frequency. The time period thus has a sufficient coverage before and after the inception of the EAEU for an empirical analysis. The global dataset provides a rich basis to form a donor pool for the weight-selection procedure in the synthetic control estimation. Data on trade flows over the period of interest have been obtained from the International Monetary Fund, Direction of Trade 
Statistics (IMF DOTS) database [17]. GDP and Population data were taken from World Development Indicators of World Bank [18]. Common language and distance variables are obtained from the CEPII Gravity Database [19]. The summary statistics are available in the Table 2.

Table 2 - Descriptive statistics

\begin{tabular}{|c|c|c|c|c|c|}
\hline Variable & Obs & Mean & Std. Dev & Min & Max \\
\hline $\operatorname{lnBT}$ & 984 & 8.05 & 1.571 & 1.787 & 11.649 \\
\hline $\ln \mathrm{GDP}$ & 984 & 13.2 & 1.052 & 10.894 & 16.458 \\
\hline $\operatorname{lnPOP}$ & 984 & 16.561 & 1.718 & 12.497 & 21.055 \\
\hline $\operatorname{lnDist}$ & 984 & 8.003 & 0.399 & 7.448 & 8.932 \\
\hline Lang & 984 & 0.049 & 0.216 & 0 & 1 \\
\hline \multicolumn{6}{|c|}{ Note - compiled by authors } \\
\hline
\end{tabular}

\section{Results and Discussion}

This section presents the results of the assessment of bilateral trade between Kazakhstan and other EAEU countries in aggregate (KAZ-EAEU), then with each country separately (KAZ-RUS, KAZ-BLR, KAZ-ARM, KAZ-KGZ). Evaluation was performed using synth command in STATA.

Although the EAEU was founded in 2014 and entered into force in 2015, in the first analysis (KAZ-EAEU) treatment period was selected as 2010 , since in this year customs union was created between Kazakhstan and two main partners - Russia and Belarus. In the second analysis, which assesses the bilateral trade of Kazakhstan with each EAEU country separately, different years were selected as the treatment period (KAZ-RUS, KAZ-BLR - 2010; KAZ-ARM, KAZ-KGZ - 2015), since Kyrgyzstan and Armenia joined the integration association only in 2015 .

Table 3 - Synthetic control group composition in KAZEAEU analysis

\begin{tabular}{|l|l|}
\hline Country & Weight \\
\hline Hungary & 0.487 \\
\hline Germany & 0.254 \\
\hline Lithuania & 0.139 \\
\hline Romania & 0.065 \\
\hline Finland & 0.029 \\
\hline Bulgaria & 0.027 \\
\hline \multicolumn{2}{|c|}{ Note - compiled by authors } \\
\hline
\end{tabular}

Table 3 reports the list of potential counterfactual units for KAZ-EAEU, together with the corresponding average weights obtained using the synthetic algorithm, where weights are chosen so that the synthetic counterfactual unit best resembles the characteristics of the corresponding unit in question during the period 1995-2009. These weights for those control countries are obtained as a result of the minimization problem described in equations 7 and 8 .

Following the minimization process, not only Kazakhstan's synthetic bilateral trade but also synthetic characteristic variables (lnGDP, lnPOP, lnDist and Lang) are also calculated, using the weights for each control country.

Table 4 - Predictor Balance

\begin{tabular}{|c|c|c|}
\hline Variable & Actual & Synthetic \\
\hline $\operatorname{lnGDP}$ & 12.06 & 12.881 \\
\hline $\operatorname{lnPOP}$ & 16.54 & 16.553 \\
\hline $\ln$ ist & 7.67 & 7.699 \\
\hline Lang & 1 & 0 \\
\hline $\operatorname{lnBT}(2009)$ & 9.501 & 9.535 \\
\hline $\operatorname{lnBT}(2005)$ & 9.224 & 9.21 \\
\hline \multicolumn{2}{|c|}{$\operatorname{lnBT}(2000)$} \\
8.376 & 8.392 \\
\hline $\operatorname{lnBT}(1995)$ & 8.413 & 8.334 \\
\hline \multicolumn{2}{|c|}{ Note - compiled by authors } \\
\hline
\end{tabular}

As evident from Table 4, the gaps between actual and synthetic outcomes and the characteristic variables are quite small.

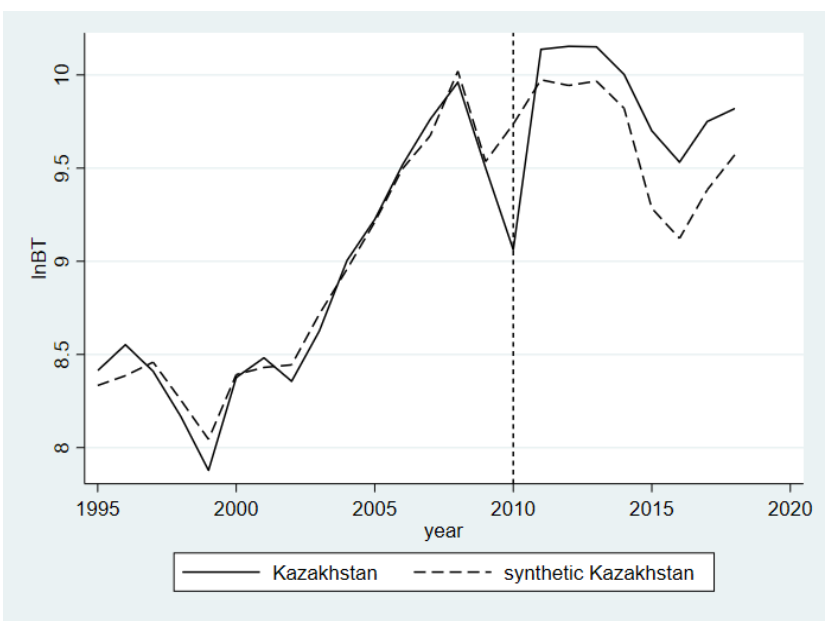

Figure 1 - Synthetic counterfactual result for KAZ-EAEU

Figure 1 plots the evolution of the bilateral trade of the KAZ-EAEU and of the synthetic units over the period 1995-2018. The solid lines display actual bilateral flows between the Kazakhstan and its 
partners from EAEU, while the dashed lines represent the average value of bilateral flows obtained from 6 synthetic counterfactuals, which were selected from 40 donor pool countries. The vertical dash line denotes the treatment year.

In the case of the pre-treatment period 19952009 , the synthetic counterfactuals provide a good approximation of the units, and the synthetic (dashed line) and actual bilateral flows (solid line) behave very similarly. After the treatment period, the series labelled 'synthetic Kazakhstan' shows what the estimated Kazakhstan's bilateral trade with the EAEU countries would have been if the EAEU had not been established. From the figure, it is clear that the realized bilateral trade is higher than the synthetic one for most years, especially after 2012. This result suggests that bilateral trade between Kazakhstan and EAEU countries would have been lower without the formation of the EAEU.

In order to calculate the quantitative value of the impact of integration on the bilateral trade of Kazakhstan with the EAEU member countries, we used non-log data (Figure 2).

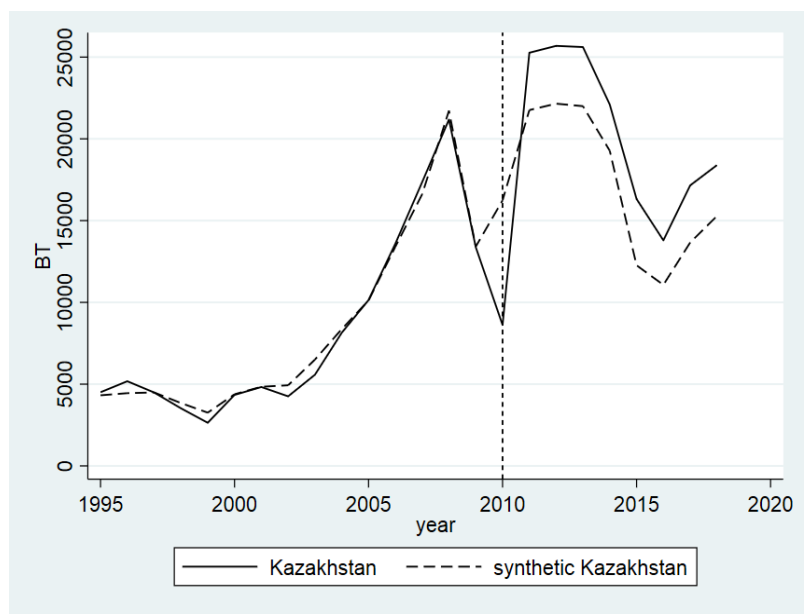

Figure 2 - Synthetic counterfactual result for KAZEAEU using non-log data

As a result, we can see on the graph that if Kazakhstan had not entered into integration, then in 2018 bilateral trade between Kazakhstan and the EAEU countries would have been $\$ 15,000$ million, instead of the actual $\$ 18,395$ million, that is, $18.5 \%$ less.

We repeated the minimization process of both the outcome and characteristic variables in order to estimate change in bilateral trade between Kazakhstan and each country-member of EAEU separately.
Figure 3 summarizes the results of the synthetic counterfactual analysis for bilateral trade between Kazakhstan and each country of EAEU.

Figure 3 shows that the impact of the Eurasian Economic Union on bilateral trade between Kazakhstan and other countries varies significantly. On the one hand, we can observe an improvement in bilateral trade Kazakhstan with Russia and Belarus compared to the counterfact scenario without integration. Moreover, on the assumption of the root mean squared prediction error (RMSPRE) (for KAZRUS - 0.065; KAZ-BLR - 0.176) and placebo tests (see below), the results are robust and statistically significant. Table 5 also shows the difference between the estimates of the actual and synthetic groups variables. It should be noted that pre-treatment outcomes for KAZ-RUS and KAZ-BLR fit well and close to zero.

However, for trade between KAZ-ARM, KAZKGZ country pairs, the Eurasian Economic Union did not show significant positive effects. Simultaneously with the join of Armenia and Kyrgyzstan into an integration association, there was a sharp deterioration in macroeconomic conditions in the Eurasian bloc. This is due to the spasmodic volatility of exchange rates and the devaluation of the currency of almost all EAEU countries. Also, given Russia's economic dominance in the EAEU, the country's economic recession under the influence of sanctions imposed against Russia caused a number of negative secondary effects for the remaining countries of the association and contributed to the deterioration of trade in general and intra-unit trade in particular.

Table 6 reports the list of potential counterfactual units for KAZ-RUS, KAZ-BLR, KAZARM, KAZ-KGZ country pairs, together with the corresponding average weights obtained using the synthetic algorithm, where weights are chosen so that the synthetic counterfactual unit best resembles the characteristics of the corresponding unit in question during the period 1995-2009 for KAZRUS, KAZ-BLR and 1995-2014 for KAZ-ARM, KAZ-KGZ. 

Bolat M. Mukhamediyev, Zhansaya S. Temerbulatova, / Экономика: стратегия и практика, № 2 (15), 2020 г.
Guliya K.Ilyashova, 55-64

KAZ-RUS

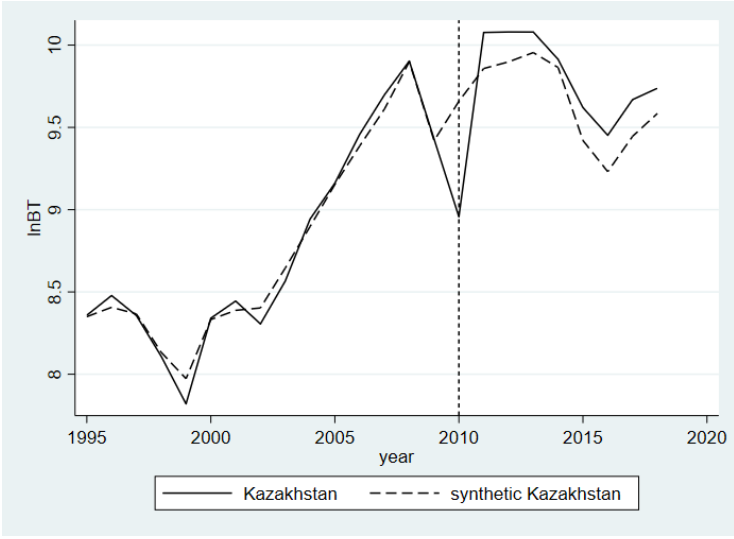

KAZ-ARM

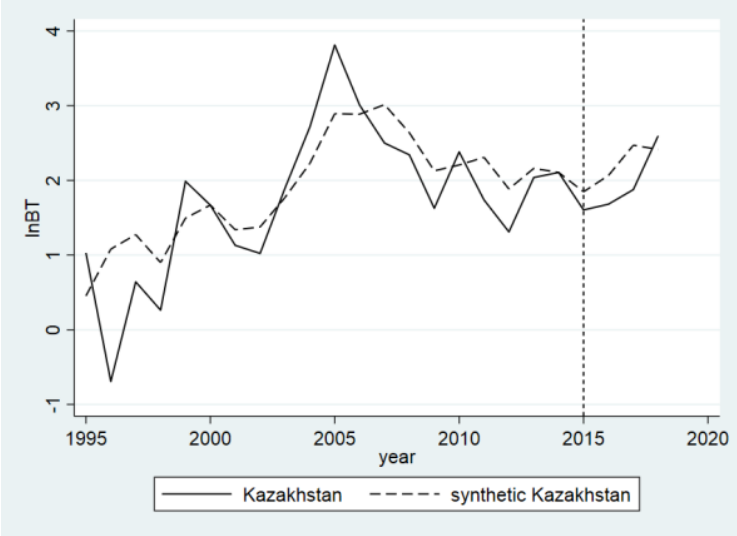

KAZ-BLR

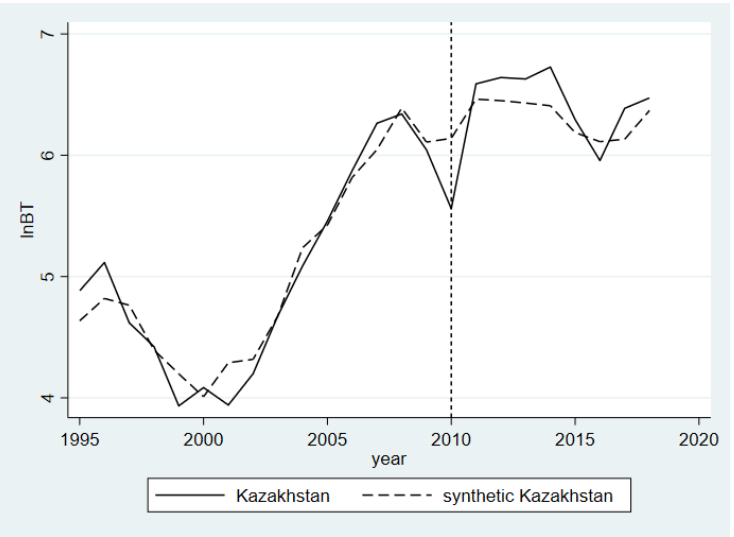

KAZ-KGZ

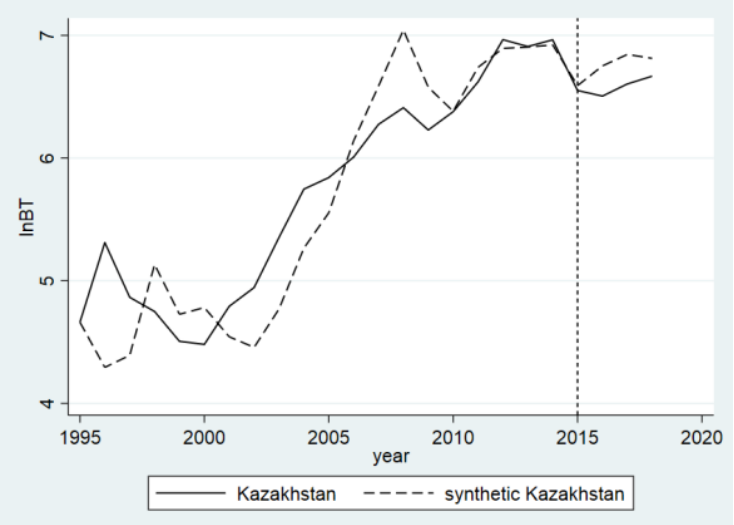

Figure 3 - Synthetic counterfactual result for KAZ-RUS, KAZ-BLR, KAZ-ARM, KAZ-KGZ

Table 5 - Difference between actual and synthetic: Kazakhstan and EAEU member-countries (1995-2009 for Russia and Belarus; 1995-2014 for Armenia and Kyrgyzstan)

\begin{tabular}{|l|c|c|c|c|}
\hline Variables Countries & Russia & Belarus & Armenia & Kyrgyzstan \\
\hline $\ln \mathrm{BT}(2014)$ & - & - & 0.0004 & 0.042 \\
\hline $\ln \mathrm{BT}(2009)$ & 0.009 & -0.064 & 0.175 & -0.003 \\
\hline $\ln \mathrm{BT}(2005)$ & 0.008 & 0.034 & 0.92 & 0.287 \\
\hline $\ln \mathrm{BT}(2000)$ & 0.008 & 0.075 & -0.001 & -0.3 \\
\hline $\ln \mathrm{BT}(1995)$ & 0.009 & 0.247 & 0.576 & 0.0007 \\
\hline $\ln \mathrm{GDP}$ & -0.73 & -0.547 & -1.117 & -3.52 \\
\hline $\ln \mathrm{POP}$ & -0.566 & 0.054 & 0.001 & -3.073 \\
\hline $\ln$ List & 0.008 & 1.431 & 0.039 & -1.377 \\
\hline Lang & 1 & 0 & 0 & 0 \\
\hline \multicolumn{2}{|c|}{ Note - compiled by authors }
\end{tabular}



Bolat M. Mukhamediyev, Zhansaya S. Temerbulatova, / Экономика: стратегия и практика, № 2 (15), 2020 г.
Guliya K.Ilyashova, 55-64

Table 6 - Synthetic control group composition in KAZ-RUS, KAZ-BLR, KAZ-ARM, KAZ-KGZ analyzes

\begin{tabular}{|c|c|c|c|c|c|c|c|}
\hline \multicolumn{2}{|c|}{ KAZ-RUS } & \multicolumn{2}{|c|}{ KAZ-BLR } & \multicolumn{2}{|c|}{ KAZ-ARM } & \multicolumn{2}{|c|}{ KAZ-KGZ } \\
\hline Country & Weight & Country & Weight & Country & Weight & Country & Weigh \\
\hline $\begin{array}{l}\text { Italy } \\
\text { Czech Republic } \\
\text { Romania } \\
\text { Korea } \\
\text { Germany } \\
\text { Singapore } \\
\text { Bulgaria }\end{array}$ & $\begin{array}{c}0.373 \\
0.289 \\
\\
0.108 \\
0.086 \\
0.08 \\
0.042 \\
0.21\end{array}$ & $\begin{array}{l}\text { Slovak } \\
\text { Republic } \\
\text { Poland } \\
\text { Lithuania } \\
\text { India } \\
\text { Bulgaria } \\
\text { Pakistan }\end{array}$ & $\begin{array}{l}0.37 \\
\\
0.239 \\
0.197 \\
0.106 \\
0.084 \\
0.004\end{array}$ & $\begin{array}{l}\text { Greece } \\
\text { Netherlands } \\
\text { Pakistan } \\
\text { Estonia }\end{array}$ & $\begin{array}{c}0.47 \\
0.237 \\
0.184 \\
0.109\end{array}$ & $\begin{array}{l}\text { China } \\
\text { Germany } \\
\text { Turkey } \\
\text { India }\end{array}$ & $\begin{array}{l}0.512 \\
0.335 \\
0.141 \\
0.012\end{array}$ \\
\hline
\end{tabular}

\section{Robustness and placebo exercises}

To assess the significance of our estimates, we conduct a series of placebo studies as described in the work of Abadie et al. by iteratively applying the synthetic control method used to estimate the effect of create EAEU in Kazakhstan to every other country in the donor pool [3]. In each iteration we reassign in our data of bilateral trade to one of the 40 control countries, shifting Kazakhstan to the donor pool. That is, we proceed as if one of the states in the donor pool would have joined to the integration association instead of Kazakhstan. We then compute the estimated effect associated with each placebo run. This iterative procedure provides us with a distribution of estimated gaps for the states where no intervention took place.

Figure 3 displays the results for the placebo test. The gray lines represent the gap associated with each of the 40 runs of the test. That is, the gray lines show the difference in bilateral trade between each country in the donor pool and its respective synthetic version. The black line denotes the gap estimated for Kazakhstan.
KAZ-EAEU

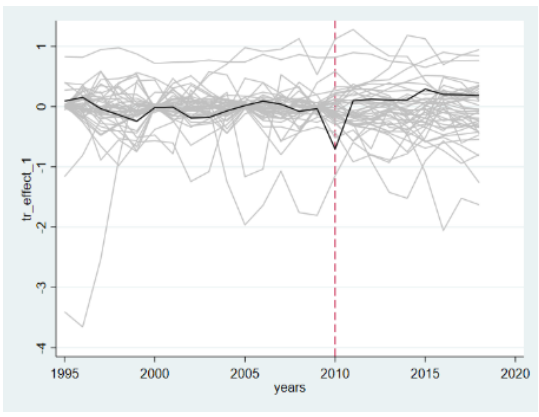

KAZ-RUS

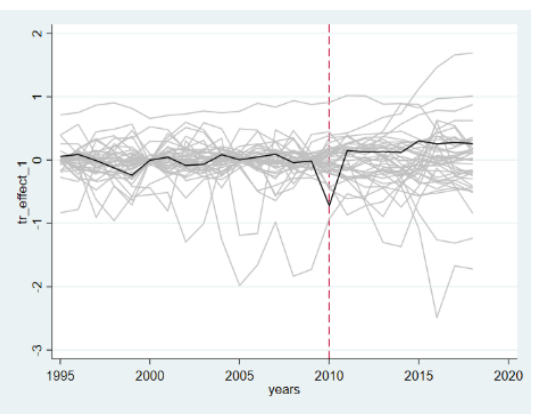

KAZ-BLR

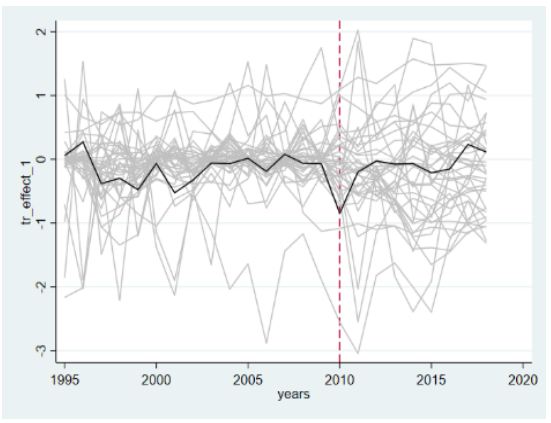

KAZ-ARM

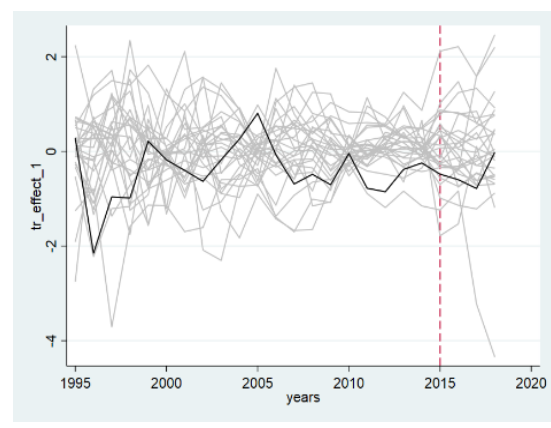

KAZ-KGZ

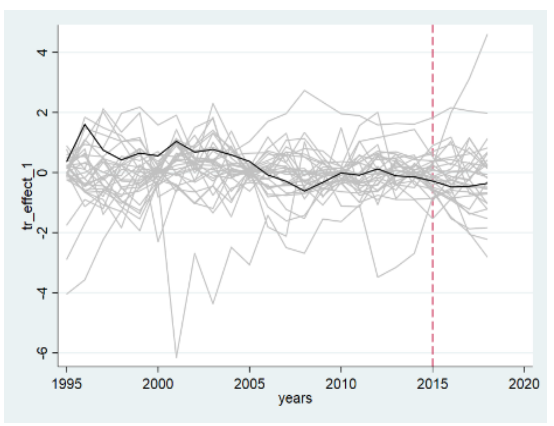

Figure 4 - Placebo test results 
As Figure 4 indicates, the synthetic method provides a good fit for bilateral trade between KAZ-EAEU and KAZ-RUS country pairs. The preintervention root mean squared prediction error (RMSPE) in KAZ-EAEU and KAZ-RUS (the average of the squared discrepancies between bilateral trade of Kazakhstan with all EAEU countries together, Russia separately and in its synthetic counterpart during the period 1995-2009) is 0.084 and 0.065 respectively. It should also be noted here that the black lines in the graphs of KAZ-EAEU and KAZ-RUS are almost the same. This suggests that the Russia is main trading partner of Kazakhstan among all EAEU countries and has the greatest impact.

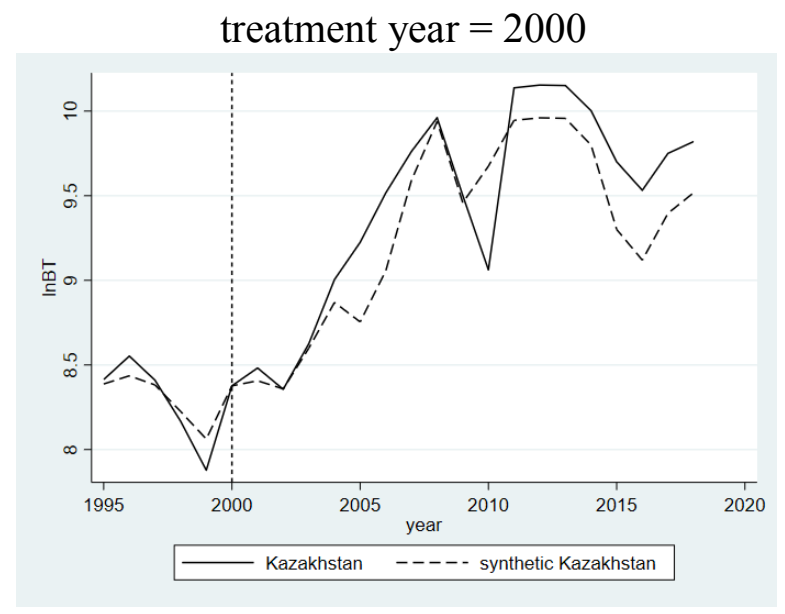

/ Экономика: стратегия и практика, № 2 (15), 2020 г.

The impact of Eurasian economic union on KAZBLR country pair is less clear, and KAZ-ARM and KAZ-KGZ results are plagued by relatively high pre-intervention RMSPE indicating difficulties in identifying a synthetic control group to closely mimic the volatile trade dynamics.

As a next robustness check, we run two in-time placebo tests as in the article of Barone [20], in which the donor pool remains fixed, the treated unit is always Kazakhstan, but the treatment year is changed. The fake treatment years are 2000 and 2005, chosen in the center of the 1995-2009 interval (Figure 5).

Figure 5 - Robustness checks: in-time placebo

Figure 5 shows that both graphs are identical with the original version, where the treatment year is 2010, and no significant divergence is observed before 2010, thus further corroborating our claim on the positive impact of integration on the bilateral trade of Kazakhstan with the EAEU countries.

\section{Conclusion}

Evaluation of the effectiveness of the functioning of the integration association is extremely important for the participating countries. In view of the fact that the creation of integration primarily involves the abolition of customs tariffs and trade barriers, the expansion of trade and the market, the effect of integration should be assessed by analyzing changes in trade flows between the participating countries.

In this article, we used the synthetic control method to assess the bilateral trade of Kazakhstan with other EAEU members. Using panel data of bilateral trade, GDP and other gravity variables for Kazakhstan and 40 donor pool countries for 1995-
2018, a counterfactual group was constructed, it allowed us to estimate bilateral trade flows that would have been between Kazakhstan and other countries of the integration bloc if Kazakhstan had not join the Eurasian Economic Union. Our results show that trade flows between Kazakhstan and the EAEU countries would have been approximately $18.5 \%$ lower without the creation of an integration bloc.

Despite numerous macroeconomic and geopolitical problems, such as the collapse of world oil prices, currency devaluation, sanctions faced by the EAEU countries in 2015-2016, the study showed the positive impact of integration on trade flows between the participating countries.

From this we can conclude that the EAEU is able to both maintain the position of member states in difficult economic situations, and help in the transition to a more competitive country, contributing to the development of the business environment to facilitate foreign direct investment and participation in global value chains. 

Bolat M. Mukhamediyev, Zhansaya S. Temerbulatova, / Экономика: стратегия и практика, № 2 (15), 2020 г.
Guliya K.Ilyashova, 55-64

\section{References}

1. Official website of Eurasian Economic Commission. Available at: http://www.eurasiancommission.org/

2. Abadie A., Gardeazabal J. (2003) The Economic Costs of Conflict: A Case Study of the Basque Country. American Economic Review, 93 (1), 112-132.

3. Abadie A., Diamond A., Hainmueller J. (2010) Synthetic control methods for comparative case studies: estimating the effect of California's tobacco control program. Journal of the American Statistical Association, 105 (490), 493-505.

4. Demko I., Jaenicke E.C. (2018) Impact of European Union-U.S. Organic Equivalency Arrangement on U.S. Exports. Applied Economic Perspectives and Policy, 40 (3), 482-501, doi:10.1093/aepp/ppx048

5. Saia A. (2017) Choosing the open sea: The cost to the UK of staying out of the euro. Journal of International Economics, 108, 82-98, doi: 10.1016/j.jinteco.2017.06.001

6. Addessi W., Biagi B., Brandano G. (2019) Evaluating the effect of the introduction of the euro on tourist flows: A synthetic control approach. The World Economy, 42(5), 1554-1575, doi: 10.1111/twec.12763

7. Nwe K., Kawata K., Yoshida Y. (2018) Recent Political Change in Myanmar and Its Impact on her Economic Growth. Asian Economic Journal, 32 (1), 39-54, doi: $10.1111 /$ asej.12141

8. Campos N.F., Coricelli F., Moretti L. (2019) Institutional integration and economic growth in Europe. Journal of Monetary Economics, 103, 88-104, doi: 10.1016/j.jmoneco.2018.08.001

9. Hosny A.S. (2012) Algeria's Trade with GAFTA Countries: A Synthetic Control Approach. Transition Studies Review, 19, 35-42, doi: 10.1007/s11300-0120228-4

10. Aytug H., Kutuk M.M., Oduncu A., Togan S. (2017) Twenty Years of the EU-Turkey Customs Union: A Synthetic Control Method Analysis. Journal of Common Market Studies, 55 (3), 419-431, doi: 10.1111/ jcms. 12490

11. Gabrielczak P., Serwach T. (2017) Economic integration and export complexity: the case of Slovakia. Lodz Economics Working papers, 6.

12. Stojcic N., Vojinic P., Aralica Z. (2018) Trade liberalization and export transformation in new EU member states. Structural Change and Economic Dynamics, 47, 114-126, doi: 10.1016/j.strueco. 2018.08.004

13. Baier S., Bergstrand J. (2009) Estimating the effects of free trade agreements on international trade flows using matching econometrics. Journal of International Economics, 77(1), 63-76, doi: 10.1016/j. jinteco.2008.09.006

14. Montalbano P., Nenci S. (2014) The Trade Competitiveness of Southern Emerging Economies: A Multidimensional Approach Through Cluster Analysis. The World Economy, 37(6), 783-810, doi: 10.111/ twec. 12195.

15. Gertler P.J., Martinez S., Premand P., Rawlings L.B., Vermeersch C.M.J. (2016) Impact Evaluation in Practice. Second Edition. International Bank for Reconstruction and Development, The World Bank.

16. Gardeazabal J., Vega-Bayo A. (2017) An empirical comparison between the synthetic control method and hsiao et al.'s panel data approach to program evaluation. Journal of Applied Econometrics, 32, 9831002, doi: $10.1002 /$ jae. 2557

17. International Monetary Fund Direction of Trade Statistics (IMF DOTS). Available at: https://data.imf. org/regular.aspx?key $=61013712$
18. World Development Indicators of World Bank. Available at: http://datatopics.worldbank.org/worlddevelopment-indicators/themes/economy.html

19. CEPII Gravity Database. Available at: http://www. cepii.fr/CEPII/en/bdd modele/download.asp?id=8

20. Barone G., David F., de Blasio G. (2016) Boulevard of broken dreams. The end of EU funding (1997: Abruzzi, Italy). Regional Science and Urban Economics, 60, 31-38, doi: 10.1016/j.regsciurbeco.2016.06.001 